aneurin. The bulletin reports effects on other plant organs of these substances of possiblo application in horticulture. It is impossible to include all the latest work ; there is no mention here of totrahydronaphthylideno acetic acid, or of $\alpha$-naphthylacetamide, recently shown to be active substances inducing cell division and root formation, or of plants failing to respond to treatment the anatomy of which is under investigation at Kew. This bulletin forms a well. balanced review of the subject to date, and its valuo is increased by its practical outlook.

\section{Earthquake in Bulgaria}

Durnag the night of 'Thursday-Friday, October 19-20, strong earthquako shocks accompanied by a roaring sound wero reported from Orisovo near Tchirpan in south Bulgaria. Some alarm was caused among the inhabitants but no damage was reported, and thus the earthqualie appears to have been of about intensity VI on the Rossi-Forel scalo (oscillation of chandeliers, visible disturbance of trees and shrubs, somo startled persons leavo their dwellings). This area is definitely seismic, and violent local shocks were reported from the same region on April 14 and April 25, 1928. According to K. Jankov, of the Observatory at Sofia, the most active region is to the south-east of Kustendil, where 1,420 shocks occurred between the years 1749 and 1936, some of these being so severo as intensity VII on tho RossiForel scale (overthrow of movablo objects, fall of plaster, etc., but no damage to buildings). The majority of the shocks appear to have been of shallow focus, only affecting a small area and prob. ably being due to slipping along an active fault. The present shock may have been of $a$ similar nature.

\section{Earth Tremor near Ottawa}

AN earth tremor of intensity IV on the modified Mercalli scale (rattling of dishes, windows, doors) shook Ottawa on Friday, October 20. No damage was done. Small earth tremors are known to occur in eastern Canada from Baffin Bay to tho Great Lakes including Newfoundland, though the nearest active epicentres to Ottawa appear to bo those of Timiskaming (Quebec), where there was a shock on November 1, 1935, and in the region of the Sanguenay River, where shocks have been recorded from as early as Fobruary 5, 1663, and continuing to the present time. Further information concerning the shock of October 20 is awaited from the Dominion Observatory at Ottawa.

\section{Discovery of Comet Giacobina-Zinner}

Aw I.A.U. telegram from Copenhagen announces that thi comet was discovered by van Biesbroeck on October 15 at $1 \mathrm{~h} .17 \cdot 1 \mathrm{~m}$. U.T. Its position is given as R.A. 16h. $21 \mathrm{~m} .27 \cdot 4 \mathrm{~s}$., N. Dec. $1^{\circ} 18^{\prime} 53^{\prime \prime}$. It is described as diffuse with central condensation, magnitude 15. In the "Handbook of the British Astronomical Association, 1939", the elements and ephemeris of this comet are given by Mr. F. R. Cripps, who applied the perturbations of Jupiter and
Saturn to tho 1933 elements. The comet is very close to the predicted position, and it is only necessary to make the corrections for perihelion passage $0 \cdot 25 \mathrm{~d}$. later than that given in the "Handbook".

\section{Rapidly Moving Spots on the Planet Jupiter}

Mr. B. M. Pfek, president of tho British Astronomical Association and director of the Jupiter Section, has observed an outbreak of small dark spots on projections at the south edge or the North Temperate Belt of Jupiter. They appear to be rotating at such a speed that a complete rotation would take place in about 9 hours $50 \frac{1}{2}$ minutes. Thero is a remarkablo similarity between these spots and those which occurred in 1880, 1891 and 1929. Astronomers in possession of telescopes with apertures of 8 inches or more should be able to see theso spots.

\section{A Large Sunspot}

A LARGE sunspot appeared over the sun's east limb on October 19 and is now crossing to the west limb, which it will reach on November 1. The timo of central meridian passage of the spot is October $26 \cdot 0$, its latitude $8^{\circ}$ south and its aroa, corrocted for foreshortening, on October 20, was 1850 millionths of the sun's hemisphere.

\section{The Night Sky in November}

THE moon is new on November 11 at $7 \cdot 9 \mathrm{~h}$. and full on November 26 at $21 \cdot 9 h$. U.T. The bright star $\lambda$ Ceminorum (magnitude $3 \cdot 6$ ) is occultod on November 30, the disappearance as seen from Greenwich taking place at $2 \mathrm{~h} .22 \cdot 8 \mathrm{~m}$. at position angle $102^{\circ}$ from the north point, and the reappearance at $3 \mathrm{~h} .37 \cdot 8 \mathrm{~m}$. at $282^{\circ}$. Mars, Jupitor and Saturn are bright planets in tho evening or night sky. In mid-November, Mars souths at about $18 \mathrm{th}$., Jupiter at $20 \frac{1}{2} \mathrm{~h}$. and Saturn at $221 \mathrm{~h}$. Jupiter is in conjunction with the moon on November 21 at $22 \mathrm{~h}$. and Saturn on November 24 at 1 . Uranus is in opposition on November 13, when its distance from the earth is nearly 1,731 million miles. Neptuno, near the border between the constellations of Virgo and Leo, makes a near approach (about 20") to the eighth magnitude star $\mathrm{BD}+3^{\circ} 2549$. At about $21 \mathrm{~h}$. in the middle of the month, the Milky Way passes from the eastern to the western horizon through tho zenith of London. Tho most distant celestial object that can be seen with the naked eye-the Great Nebula in Andromeda-is on the meridian at an altitude of $79^{\circ}$. Vega is the brightest star in the north-west quadrant of the sky and Capella the brightest in the north-east. The Pleiades cluster is well above the eastern horizon, and Orion is then just rising. The Lconid meteors should be looked for about November 14-16; their radiant point, preceding $\gamma$ Leonis, rises about $23 \mathrm{~h}$. Tho meteors of this well-known shower aro characterized by swift flights and their greenish colour. Light variations in the variable star Algol ( $\beta$ Persei) may bo noticed about ono and a half hours before and after the following times of primary minima : November $14 \mathrm{~d} .3 \cdot 1 \mathrm{~h} . ; 16 \mathrm{~d} .23 \cdot 9 \mathrm{~h} . ; 19 \mathrm{~d}$. $20 \cdot 8 \mathrm{~h}$. and $22 \mathrm{~d}$. $17 \cdot 6 \mathrm{~h}$. 